\title{
Observations on the feeding behavior of the Sierra de Aroa shrew (Cryptotis aroensis, Eulipotyphla: Soricidae), in Venezuela
}

\author{
Franger J. García ${ }^{1 *}$, Marjorie Machado ${ }^{1}$, Mariana Isabel Delgado-Jaramillo ${ }^{1,2}$ and Oriana Vásquez-Parra ${ }^{1}$ \\ ${ }^{1}$ Centro de Estudios en Zoología Aplicada (CEZA), Laboratorio Museo de Zoología (MZUC), Departamento de Biología, Facultad \\ Experimental de Ciencias y Tecnología (FACyT), Universidad de Carabobo, Valencia. Estado Carabobo, Venezuela. Email: \\ cormura@yahoo.com (FJG), marjomachado@hotmail.com (MM), Oriyoli@hotmail.com (OVP). \\ 2 Laboratório de Ciência Aplicada à Conservação da Biodiversidade, Departamento de Zoologia, Universidade Federal de \\ Pernambuco, Rua Nelson Chaves s/n, Cidade Universitária-Recife PE 50670-420. Pernambuco, Brasil. E-mail: marianadelgado13@ \\ yahoo.es (MID) \\ * Corresponding author
}

The shrew Cryptotis aroensis from Sierra de Aroa, Venezuela, was recently described. Little is known on the natural history of the species. This note reports the first records on the foraging behavior of $C$. aroensis in captivity feeding on invertebrates and small vertebrates. We placed one individual previously captured in a pitfall trap inside a plastic box for ten days. We also added litter, log remains, bromeliads and mosses inside the box. Potential invertebrate and vertebrate preys were captured and placed simultaneously with the shrew to make observations on locomotion, posture, feeding preferences and prey manipulation. We supplied 17 invertebrate and two small vertebrate preys belonging to three phyla and seven classes during the period of captivity (Table 1). The foraging behavior consisted of sniffing the substrate and air (Figure $1 \mathrm{~A}, \mathrm{~B})$. The stalking behavior on prey consisted of rapid movements above or under the litter, and catches were made directly with the snout (Figure 1C, D). Handling prey for consumption involved tearing, cutting and chewing a small portion; the same pattern was repeated until the prey was consumed completely. Cryptotis aroensis consumed a variety of prey, but it showed no apparent preference for any prey, contrary to what was reported for C. meridensis in Merida, Venezuela (Woodman and Diaz de Pascual 2004). C. aroensis differed from C. meridensis in the search and capture strategies, but coincided with C. parvus (Whitaker 1974). Although the information reported in this note should not be taken as conclusive because it derived from a single individual under inadequate study conditions; nonetheless, it represents the first record on the behavior of the species in captivity.

La musaraña, Cryptotis aroensis fue descrita recientemente de la Sierra de Aroa, Venezuela. Poco se sabe de la historia natural de la especie. Esta nota presenta los primeros registros obtenidos de comportamiento de depredación y alimentación de C. aroensis sobre animales invertebrados y pequeños vertebrados en cautiverio. Se colocó un ejemplar previamente capturado en un sistema de trampas de fosa adentro de una caja de plástico por diez días. La caja fue ambientada con hojarasca, restos de troncos, bromelias y musgos. Se colectaron potenciales presas de invertebrados y vertebrados que fueron colocadas simultáneamente con la musaraña para hacer observaciones de locomoción, postura, preferencias alimentarias y manipulación de las presas. En el periodo de cautiverio se le suministró al ejemplar de $C$. aroensis 17 presas de invertebrados y dos pequeños vertebrados pertenecientes a tres Phyla y siete Clases (Tabla 1). El comportamiento de exploración consistió en "olfatear" sobre el sustrato y aire (Figura 1A, B). El comportamiento de acecho de las presas fueron rápidos movimientos por encima o por debajo de la hojarasca y las capturas fueron realizadas directamente con su hocico (Figura 1C, D). La manipulación de las presas para el consumo fue desgarrar, cortar y masticar una pequeña porción y luego volver a repetir el mismo patrón hasta consumirlos completamente. Cryptotis aroensis consumió a varias de las presas suministradas, sin aparentemente mostrar un comportamiento de preferencia por alguna, contrario a lo reportado para C. meridensis en Mérida, Venezuela (Woodman and Díaz de Pascual 2004). El comportamiento de búsqueda y captura, igualmente fue distinto al reportado para C. meridensis, pero coincidió con C. parvus (Whitaker 1974). Aunque los datos presentados en esta nota no deben de tomarse como conclusivos debido a que los ensayos fueron realizados con un solo individuo y las condiciones para el estudio no fueron las adecuadas, representan los primeros registros sobre el comportamiento en cautiverio de la especie.

Key words: foraging behavior; shrew; Sierra de Aroa; Yaracuy, Venezuela.

๑ 2017 Asociación Mexicana de Mastozoología, www.mastozoologiamexicana.org

\section{Introduction}

The shrew Cryptotis aroensis from Venezuela was recently described, and to date is known only from three locations in Sierra de Aroa, municipality of Bolívar, Yaracuy State: Capilla de Milla (type locality; Quiroga-Carmona and Molinari 2012), El Silencio and La Trampa del Tigre (Yurubí National Park; García et al. 2013). Nothing is known about the diet and foraging behavior of $C$. aroensis.

In an inventory on mammals inhabiting humid forests at Yurubí National Park, Sierra de Aroa, Venezuela (García et al. 2013), an adult female of $C$. aroensis was captured in a pitfall trap fitted with a drift fence placed in the area known as "La Trampa del Tigre" (10 $24^{\prime} 11^{\prime \prime} \mathrm{N}, 68^{\circ} 48^{\prime} 01^{\prime \prime} \mathrm{W}, 1,700$ $\mathrm{m})$. The finding of this animal offered the opportunity to document the first observations related to its activity and foraging behavior over a short period of time in captivity.

\section{Materials and Methods}

Since the capture of a living $C$. aroensis in the pitfall trap was unexpected (most of the time, these animals do not remain alive after being caught up in these traps), an improvised site had to be conditioned for the handling and mainte- 
nance of the shrew in the base camp at Yurubí National Park; in addition, a method was designed for the observations and collection of prey items used as food. For further details on the habitat, population and ecological aspects of C. aroensis, refer to (García et al. 2013; Quiroga-Carmona and Molinari 2012).

The specimen of $C$. aroensis (adult; weight $=11.0 \mathrm{~g}$ ) was placed in a plastic box $(50 \mathrm{~cm}$ long $\times 35 \mathrm{~cm}$ wide $\times 35 \mathrm{~cm}$ high) for ten days (May 16 to 25, 2012). The box was conditioned with a thin layer of litter, log remains, bromeliads
(Guzmania spp.) and mosses. Ambient temperature in the locality over the course of the experiment ranged from 10 ${ }^{\circ} \mathrm{C}$ at night to $25^{\circ} \mathrm{C}$ in daytime. When the experiments were completed, the animal was sacrificed, processed as biological material (skin, skull and skeleton), and deposited in the Museo de la Estación Biológica de Rancho, Aragua State, Venezuela, under catalog number EBRG-29398. The scientific collection license granted by the Ministerio del Poder Popular para el Ambiente was registered under number 3411.

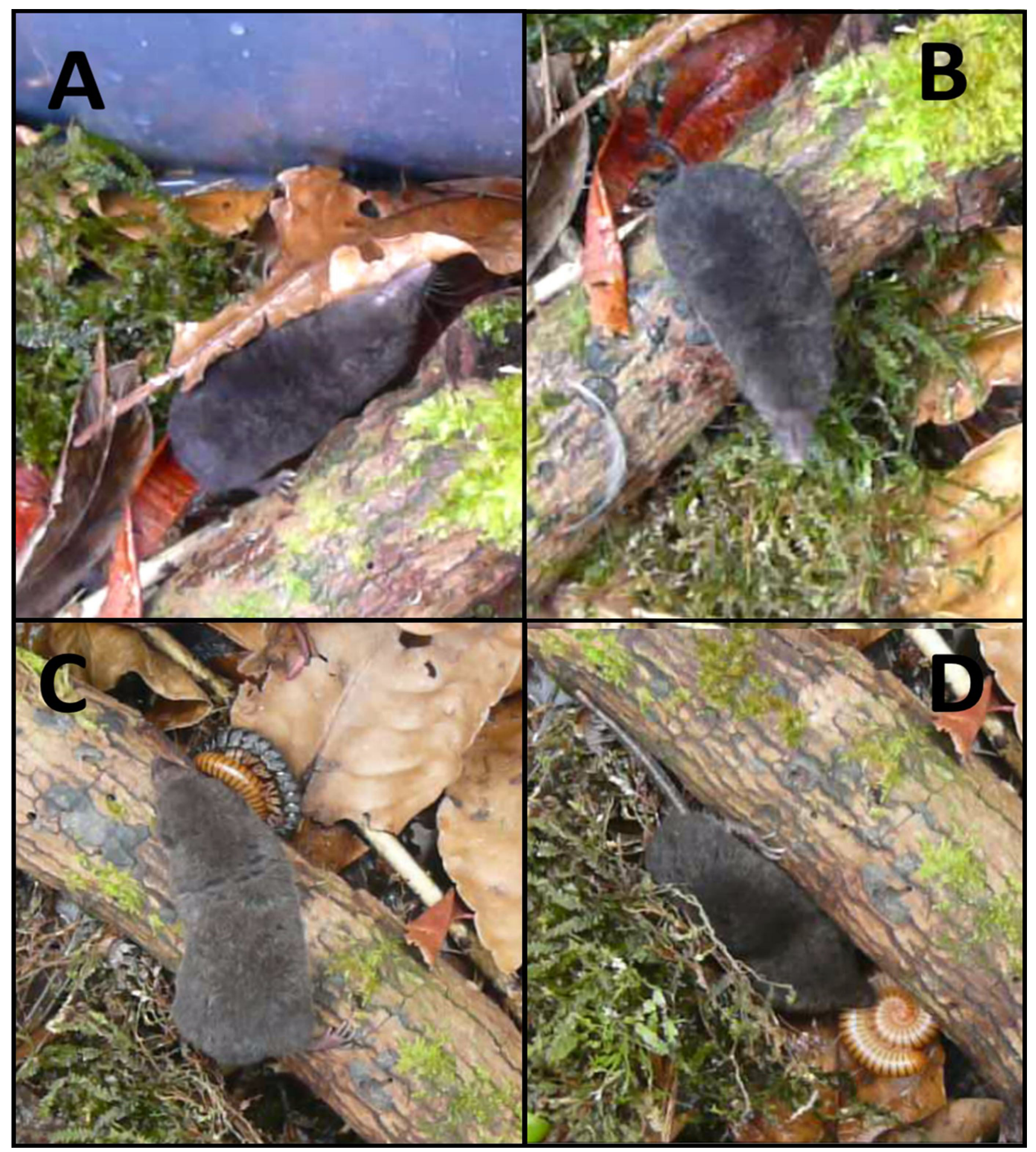

Figure 1. Transformed images of visual records that show a female of Cryptotis aroensis in the search phases and interacting with invertebrate preys (Chilopoda and Diplopoda). In

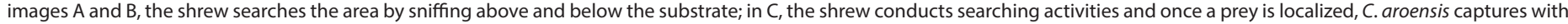
its snout and takes it to a shelter to consume it (D). 
Potential preys were divided into three categories: soft body and size $<50 \mathrm{~mm}$; hard body and size $<50 \mathrm{~mm}$; and soft or hard body and size $>50 \mathrm{~mm}$. Prey items were placed inside the box simultaneously (every two hours from 18:00 until 06:00 hours). Most of them were offered in equal amounts, every day, and visual records were made simultaneously with a digital camera to document locomotion, posture, food preferences and prey manipulation.

\section{Results}

A total of 17 invertebrate and two small vertebrate preys belonging to three phyla and seven classes were supplied to $C$. aroensis (Table 1). With regard to behavior, observations were the following: at the beginning of the activity (approximately 18:00 hours), the shrew moved quickly using its four legs; no jumps were observed. Very often, it stopped to sniff out the air as well as above and under the substrate (Figure 1A, B). Then, it resumed rapid movements in a straight line over the edge and the central portion of the box; these movements were a combination of displace- ment above and under the litter layer. In the few moments of inactivity observed (from 20:00 hours and approximately every three hours), the shrew rested above the substrate or hidden under the litter or among small logs.

When a prey was detected, the shrew approached it quickly above or below the litter and captured it with the snout (Figure 1D). All capture attempts at the first encounter involved a quick bite to the anterior or posterior region of the prey's body, immediately followed by another quick bite to attract the prey toward itself. These catches were 100 $\%$ effective in the first encounter with annelids (Annelida), sawbugs (Oniscidea), beetle larvae (Coleoptera) and geckos (Gonatodes rapicauda and Thecadactylus falconensis).

When the first bite was unsuccessful, the prey escaped (mostly Blattide, Acrididae, Gryllidae and Grillotalpa sp.), forcing the shrew to chase it; when it reached the prey, the shrew bit it repeatedly at the back portion of the body (rear end of the abdomen and legs). In other cases, C. aroensis completely ignored the prey (Opiliones, Hymenoptera, Chilopoda, Diplopoda and Lepidoptera larvae).

Table 1. Potential prey types supplied to Cryptotis aroensis during the experimental phase.

\begin{tabular}{|c|c|c|c|c|c|}
\hline TAXA & Body consistency & Size class (mm) & Consumed & Consumption time (min) & Individuals per day \\
\hline \multicolumn{6}{|l|}{ ANNELIDA } \\
\hline \multicolumn{6}{|l|}{ Olygochaeta } \\
\hline Lumbricus sp. & soft & $<y>50$ & YES & $<3$ & 6 \\
\hline \multicolumn{6}{|l|}{ ARTHROPODA } \\
\hline \multicolumn{6}{|l|}{ Arachnida } \\
\hline Aranae & soft & $<50$ & YES & $<3$ & 4 \\
\hline \multicolumn{6}{|l|}{ Scorpionida } \\
\hline Tityus falconensis & hard & 50 & YES & $>5$ & 1 \\
\hline Opiliones & soft & $<50$ & NO & & 6 \\
\hline \multicolumn{6}{|l|}{ Malacostraca } \\
\hline \multicolumn{6}{|l|}{ Decapoda } \\
\hline Pseudothelphusa sp. & hard & $<50$ & YES & $>5$ & 1 \\
\hline Oniscidea & soft & $<50$ & YES & $<3$ & 6 \\
\hline \multicolumn{6}{|l|}{ Chilopoda } \\
\hline Scolopendridae & soft & $<50$ & YES & $>5$ & \\
\hline Morfo 1 & hard & $>50$ & NO & & 2 \\
\hline Diplopoda & hard & $>50$ & NO & & 2 \\
\hline \multicolumn{6}{|l|}{ Insecta } \\
\hline \multicolumn{6}{|l|}{ Orthoptera } \\
\hline Acrididae & hard & $<50$ & YES & $<3$ & 6 \\
\hline Gryllidae & hard & $<50$ & YES & $<3$ & 6 \\
\hline \multicolumn{6}{|l|}{ Gryllotalpidae } \\
\hline Grillotalpa sp. & hard & $<50$ & YES & $<3$ & 6 \\
\hline \multicolumn{6}{|l|}{ Blattaria } \\
\hline Blaberidae & soft & $<50$ & YES & $<3$ & 6 \\
\hline \multicolumn{6}{|l|}{ Coleoptera } \\
\hline Carabidae & hard & $<50$ & YES & $<3$ & 4 \\
\hline Scarabaeidae (Larva) & soft & $<50$ & YES & $<3$ & 6 \\
\hline Lepidoptera (Larva) & soft & $>50$ & NO & & 2 \\
\hline \multicolumn{6}{|l|}{ Hymenoptera } \\
\hline Formicidae & hard & $<50$ & NO & & 6 \\
\hline \multicolumn{6}{|l|}{ CHORDATA } \\
\hline \multicolumn{6}{|l|}{ Reptilia } \\
\hline Gonatodes falconensis & soft & $<50$ & YES & $>5$ & 1 \\
\hline Thecadactylus rapicauda & soft & $<50$ & YES & $>5$ & 1 \\
\hline
\end{tabular}


Prey handling for consumption consisted in tearing, cutting and chewing a small portion, and then repeating this same pattern until the prey was eaten up completely. The time taken to consume a prey ranged from two to three minutes for crickets and grasshoppers (Gryllidae), mole crickets (Gryllotalpa sp.) and cockroaches (Blattaria), up to over five minutes for the rest (Table 1).

\section{Discussion}

Under laboratory conditions, Woodman and Díaz de Pascual (2004) reported the consumption of a variety of invertebrates by a female Merida shrew (Cryptotis meridensis) observed over one month. The experiments conducted with C. meridensis documented its preference for earthworms (Lumbricus sp.); the feeding pattern involved search runs followed by patterns of circular movements and audible sounds in each of the search phases. Unlike those observations, $C$. aroensis showed no apparent preference for Lumbricus; during the experiments, all animals preyed upon were consumed in equal amounts, with neither patterns of circular movement nor audible sounds produced at the time of stalking and search.

Another study on Cryptotis parvus (Whitaker 1974) recorded the consumption of a large amount of invertebrates, amphibians, reptiles and small mammals by the shrew. The author mentions previous studies with $C$. parvus specimens in captivity evidencing a behavior similar to the one observed here for $C$. aroensis. In most encounters of $C$. parvus with its prey, the latter were captured by the head; some tried to escape and were chased and bitten on the head. Others were ignored and those with a soft body were consumed completely. In all observations of $C$. aroensis, the shrew never used the front legs or adopted a bipedal posture for prey handling and consumption, as recorded for other small mammals with similar prey preferences (Martin and González-Chávez 2015).

Some studies suggest that the external morphology of the legs among the different groups of species in the genus Cryptotis (particularly the development of the front legs with claws and humerus), provides information on their evolutionary history and food preferences (e. g., Woodman et al. 2003; Woodman and Morgan 2005). In the case of $C$. aroensis, Quiroga-Carmona and Molinari (2012) propose an apparent association with a more specialized diet including underground prey, due to the ease of digging provided by its developed front legs. In the trials conducted with the $C$. aroensis female, no direct evidence of digging or making tunnels and shelters was observed, as previously noted for the shrew C. meridensis under natural conditions (Díaz de Pascual and Woodman 2004, Linares 1998), but its ability to penetrate beneath the moss layer and litter when displacing was observed.

The lack of evidence of a more underground behavior of C. aroensis is likely due to the fact that the litter-moss layer was not too thick and contained no mineral sandy or clayey soil that could restrain the movements when the shrew attempted to move under the surface. Another potential explanation is that underground preys (e. g., Lumbricus sp., Scolopendridae), did not have the opportunity to escape and hid under the substrate, so that the shrew was not forced to dig for them; or maybe the duration of the experiment was insufficient to document all possible behaviors of the species.

\section{Literature cited}

Díaz de Pascual, A., and A. De Ascenção. 2000. Diet of the cloud forest shrew Cryptotis meridensis (Insectivora: Soricidae) in the Venezuelan Andes. Acta Theriologica 45:13-24.

Garcia, F. J., M. I. Delgado-Jaramillo, M. Machado, L. Aular, and Y. MúsıcA. 2013. Pequeños mamíferos no voladores de un bosque nublado del Parque Nacional Yurubí, Estado Yaracuy, Venezuela: abundancias relativas y estructura poblacional. Interciencia 38:19-725.

Linares, O. J. 1998. Mamíferos de Venezuela. Sociedad Conservacionista Audubon de Venezuela. Caracas, Venezuela.

Martin, G. M., and B. González-Chávez. 2015. Observations on the behavior of Caenolestes fuliginosus (Tomes, 1863) (Marsupialia, Paucituberculata, Caenolestidae) in captivity. Journal of Mammalogy 97:568-575.

Quiroga-Carmona, M., AND J. Molinari. 2012. Description of a new shrew of the genus Cryptotis (Mammalia: Soricomorpha: Soricidae) from the Sierra de Aroa, an isolated mountain range in northwestern Venezuela, with remarks on biogeography and conservation. Zootaxa 3441:1-20.

WhitAKER, J. O. 1974. Cryptotis parva. Mammalian Species 43:1-8.

Woodman, N., C. A. Cuartas-Calles, and C. A. Delgado-V. 2003. The humerus of Cryptotis colombiana and its bearing on the species' phylogenetic relationships (Soricomorpha: Soricidae). Journal of Mammalogy 84:832-839.

Woodman, N., and A. Díaz De Pascual. 2004. Cryptotis meridensis. Mammalian Species 761:1-5.

Woodman, N., AND J. J. P. Morgan. 2005. Skeletal morphology of the forefoot in shrews (Mammalia: Soricidae) of the genus Cryptotis, as revealed by digital X-rays. Journal of Morphology 266:60-73. 